University of Nebraska - Lincoln

DigitalCommons@University of Nebraska - Lincoln

\title{
Life Cycle and Paratenesis of American Gordiids (Nematomorpha: Gordiida)
}

\author{
Ben Hanelt \\ University of New Mexico, bhanelt@unm.edu \\ John J. Janovy Jr. \\ University of Nebraska - Lincoln, jjanovy1@unl.edu
}

Hanelt, Ben and Janovy, John J. Jr., "Life Cycle and Paratenesis of American Gordiids (Nematomorpha: Gordiida)" (2004). John Janovy Publications. 6. https://digitalcommons.unl.edu/bioscijanovy/6

This Article is brought to you for free and open access by the Papers in the Biological Sciences at DigitalCommons@University of Nebraska - Lincoln. It has been accepted for inclusion in John Janovy Publications by an authorized administrator of DigitalCommons@University of Nebraska - Lincoln. 


\title{
LIFE CYCLE AND PARATENESIS OF AMERICAN GORDIIDS (NEMATOMORPHA: GORDIIDA)
}

\author{
B. Hanelt ${ }^{\star}$ and J. Janovy, Jr. \\ School of Biological Sciences, University of Nebraska-Lincoln, Lincoln, Nebraska 68588. e-mail: bhanelt@unm.edu
}

\begin{abstract}
To complete their life cycle, gordiids must make a transition from aquatic to terrestrial environments. However, epibenthic aquatic larvae and their terrestrial definitive hosts do not overlap in habitat. This has led many investigators to suggest that infections are acquired through the ingestion of insects, which become infected as aquatic larvae with gordiid cysts and subsequently carry gordiids to land. This proposed life cycle was experimentally tested using 3 common American species of gordiids: Gordius robustus, Paragordius varius, and Chordodes morgani. Cysts of all 3 species survived the metamorphosis of Tanytarsus sp., a midge. Subsequent infection trials of definitive hosts with cysts from imagos show that cysts surviving the metamorphosis of insects remained viable and free of host internal defense reaction. Data from naturally infected mayflies, Callibaetus sp., show that encystment and survival of gordiids within aquatic insects occur in nature. Paratenesis between paratenic hosts was also shown to be possible in these 3 species. This latter finding appears to indicate that cysts formed in spurious paratenic hosts may not be lost but may eventually transfer to normal paratenic hosts.
\end{abstract}

Juvenile freshwater nematomorphs (Nematomorpha: Gordiida) or gordiids are obligatory parasites of terrestrial arthropods. Within this definitive host, worms complete development but do not mate and oviposit until free living in aquatic environments. Eggs hatch larvae, which are mobile, but cannot swim. These larvae are capable of entering a wide range of paratenic hosts. Within these hosts, larvae penetrate through the gut, secret a cyst wall, fold up, and become cysts.

Whether definitive hosts are infected by larvae or cysts has been discussed for $150 \mathrm{yr}$ (Meissner, 1856). Surprisingly, only a handful of studies have experimentally addressed this question. Some of these studies, often cited in current secondary literature, did not include control groups or used field-collected insects as hosts (Blunk, 1922a, 1922b; Thorne, 1940). Thus, these studies must be interpreted with caution. However, there is evidence suggesting that cysts are a more common method of infection of definitive hosts. First, laboratory infections of definitive hosts with larvae are less successful than those with cysts (Inoue, 1962; Hanelt and Janovy, 2004). Second, because larvae do not swim, and terrestrial arthropods do not feed in epibenthic environments, the trophic gap between the gordiid larvae and the definitive host must be overcome by the use of a paratenic host.

The identity of natural paratenic hosts, able to become infected with cysts and carry them to the terrestrial host, is still not clear. The type of paratenic host involved in these life cycles may differ depending on the type of definitive host. Gordiids using terrestrial carabid beetles as definitive hosts, which feed as generalists or carnivores, include most European and at least 1 North American species. These parasites have an unknown life cycle, although it has been proposed that paratenic hosts could include semiaquatic invertebrates such as earthworms and tipulid larvae (Schmidt-Rhaesa, 1997; Bolek and Coggins, 2002). Gordiids using mantid hosts, which feed by predation, have been shown to be able to use aquatic insects as paratenic hosts (Inoue, 1960, 1962).

In North America, most gordiid species use orthopteran hosts, which feed omnivorously. Gordius robustus Leidy, 1851, has been shown to become infected experimentally through

Received 8 January 2003; revised 24 August 2003; accepted 18 August 2003.

* Present address: Department of Biology, 163 Castetter Hall, University of New Mexico, Albuquerque, New Mexico 87131. cysts from terrestrial beetles (Hanelt and Janovy, 1999). However, this life cycle is improbable in nature because these beetles are as unlikely as the terrestrial definitive host to encounter epibenthic gordiid larvae. A role for an aquatic insect paratenic host has thus also been suspected for North American gordiids. Several gordiid species using orthopteran definitive hosts were shown to encyst within aquatic insect larvae (White, 1969; Hanelt and Janovy, 2003). Although these and above cited studies appear to support the possibility of an aquatic insect paratenic host in the life cycle of gordiids, some evidence suggests that insects may not naturally be able to serve as paratenic hosts.

First, it was shown that some insects produce an internal defense reaction (IDR) to gordiid cysts. The IDR of hosts was found to be variable, but resulted in a decreased cyst viability in certain species (Inoue, 1960). Other studies have shown that mosquitoes are able to mount a much more successful defense against cysts, resulting in the destruction and removal of cysts (Poinar and Doelman, 1974; Hanelt and Janovy, 2003). Second, a study of naturally infected insect larvae, reported that individuals infected with cysts differed morphologically and developmentally compared to uninfected individuals leading to the failure of metamorphosis in some species (White, 1969). If paratenic hosts are able to destroy cysts or are unable to develop to winged adults due to the presence of cysts, these insects will not be able to act as natural paratenic hosts. Thus, studies are needed to investigate how commonly gordiid cysts survive the metamorphosis of the insect paratenic host, and remain viable. Furthermore, the presence and survival of cysts in adult insects resulting from natural infections must also be documented to support such a life cycle in nature.

A further point, which needs to be resolved, is the fate of cysts in spurious hosts. Spurious paratenic hosts are those that are unable to act as natural hosts. Cysts of 3 common American gordiid species were recently found to readily encyst in almost any animal, including groups such as fish, amphipods, and copepods (Hanelt and Janovy, 2003). Hosts such as these obviously play no part in the natural life cycle involving a terrestrial definitive host. Studies are lacking on whether cysts in these kinds of hosts can be transmitted from one paratenic host to another, known as paratenesis, and whether these cysts could eventually be transmitted to a normal paratenic host.

To resolve the life cycle and transmission of common North American gordiids, cyst survival was studied in G. robustus 


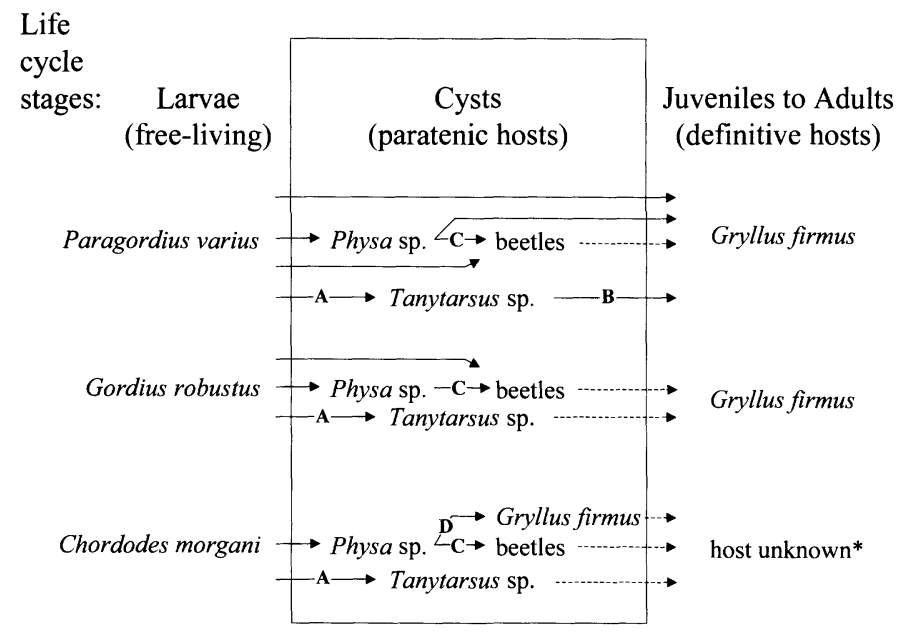

Figure 1. Possible life cycles of 3 species of gordiids. Solid lines indicate tested transmission events. Solid lines with letters indicate experiments done in this contribution; solid lines without letters indicate experiments published elsewhere. Dashed lines indicate probable transmission events. The label "beetle" refers to Zophobas sp. and Tenebrio molitor. Asterisk indicates that previously described hosts include species of Orthoptera and Blattodera.

Leidy, 1851, Paragordius varius (Leidy, 1851), and Chordodes morgani Montgomery, 1898. This study had 4 main goals: (1) to test whether cysts of common American species can persist through the metamorphosis of an aquatic insect host; (2) to test the viability of such cysts within imagos; (3) to investigate this process in the natural environment; and (4) to investigate whether cysts can be passed serially from one paratenic host to another.

\section{MATERIALS AND METHODS}

\section{Metamorphosis survival}

Adult $G$. robustus specimens were collected from small puddles at the Fourth of July Canyon in the Cibola National Forest $\left(34.794^{\circ} \mathrm{N}\right.$ $106.372^{\circ} \mathrm{W}$ ), located in the Manzano Mountains, Bernallio County, New Mexico. Paragordius varius were maintained as a laboratory culture, originally isolated from a population from Lancaster County, Nebraska (Hanelt and Janovy, 2004). Adult Chordodes morgani were collected from Elk Creek $\left(40.886^{\circ} \mathrm{N}, 96.834^{\circ} \mathrm{W}\right)$, located $11 \mathrm{~km}$ northwest of Lincoln, Lancaster County, Nebraska. Gordiid adults were maintained, and eggs were collected, as described previously (Hanelt and Janovy, 2003).

Midge larvae, Tanytarsus sp. (Insecta: Diptera), were collected from the toe drain of Lake McConaughy $\left(41.232^{\circ} \mathrm{N}, 101.669^{\circ} \mathrm{W}\right)$, Keith County, Nebraska. As a negative control group, 30 individuals were examined for the presence of gordiid cysts at the beginning of the experiment. Larvae were placed in $2-\mathrm{L}$ glass dishes in aerated spring water with 500-1,000 freshly hatched gordiid larvae of each of the 3 species. Exposed midge larvae were fed Roti-Rich ${ }^{\circledR}$ (Florida Aqua Farms, Dade City, Florida) as well as TetraMin ${ }^{\circledR}$ fish food (Tetra Sales, Blacksburg, Virginia) every second day. Water was changed on a daily basis. Dishes containing midge larvae were kept inside an insect cage to catch adult flies emerging after metamorphosis (Fig. 1, part A).

Because 5 days are required for cysts to form completely (B. Hanelt pers. obs.), midges hatching between 1 and 5 days postexposure (DPE) were removed from the cage and not examined. Starting at 5 DPE, hatched adult midges were collected and examined for the presence of cysts. Adult midges were caught by use of an aspirator and prepared using a wet mount; specimens were then placed on a slide with a drop of water, covered with a coverslip, and examined by light microscopy.
TABLE I. Survival of gordiid cysts through metamorphosis of Tanytarsus sp., exposed to Gordius robustus, Paragordius varius, and Chordodes morgani $(\mathrm{n}=20$ for each group).

\begin{tabular}{lccc}
\hline & G. robustus & P. varius & C. morgani \\
\hline Prevalence & 0.7 & 0.4 & 0.5 \\
Mean intensity & 3.6 & 2.8 & 6.0 \\
\hline
\end{tabular}

\section{Viability of cysts}

To test for gordiid cyst viability in imagos, individual adult Tanytarsus sp. containing cysts were fed to 1-day starved Gryllus firmus Scudder, 1902 (Orthoptera: Gryllidae), adult females (Fig. 1, part B). Crickets subsequently were maintained on an ad libitum diet of commercial dog food and water. Crickets were examined 30 DPE for the presence of worms by methods described previously (Hanelt and Janovy, 2004). Because of the limited availability of material, only $P$. varius cysts were tested for viability.

\section{Natural system}

To test whether cysts occur in imagos naturally, field collections were made of Callibaetis sp. (Insecta: Ephemeroptera). Callibaetis sp. larvae were collected from White Gate Creek $\left(41.202^{\circ} \mathrm{N}, 101.661^{\circ} \mathrm{W}\right)$, Keith County, Nebraska. Only Gordius difficilis (Smith, 1994) has been reported at this site (Hanelt and Janovy, 2000). Midge larvae were returned to the laboratory and placed in a $15-\mathrm{L}$ bucket with aerated spring water. A screened cage was used to enclose the top of the bucket to catch emerging adult mayflies. Eight mayfly naiads were dissected to confirm the presence of gordiid larvae. From 1 to 10 days after collection, emerging adults were collected in a cage set above the bucket and dissected as described above.

\section{Serial cyst passage}

To test whether cysts can be passed from one paratenic host to another, cysts from individual snails, Physa gyrina Say, 1821 (Mollusca: Gastropoda), were fed to the putative paratenic hosts, Tenebrio molitor Linnaeus, 1758, and Zophobas sp. (Insecta: Coleoptera) from laboratory cultures (Fig. 1, part C). These beetles cannot act as definitive hosts for the 3 species of gordiids under consideration. Control groups of 30 individuals of each potential host group were examined for natural gordiid infection. Infections were attempted by feeding a piece of snail tissue containing cysts to potential host individuals (Hanelt and Janovy, 2004). Beetles were maintained in 250-ml glass dishes and fed an ad libitum diet of commercial wheat bran and potato slices. Exposed animals were examined from 10 to 30 DPE by making a wet mount of the entire gut after it was opened longitudinally. Some of these hosts were maintained for up to 42 days to check for the persistence of cysts.

Paragordius varius, as well as $G$. robustus, can use G. firmus as a host (Hanelt and Janovy, 1999, 2004). Exposure of $G$. firmus to $C$. morgani has not led to infection. Thus, cysts of $P$. varius and G. robustus fed to G. firmus will develop into adults; however, it is not known what happens to cysts of $C$. morgani in this host. Thus, $C$. morgani cysts were fed to G. firmus individuals to determine whether cysts are passed paratenically (Fig. 1, part D). Crickets were also examined 10-30 DPE, but in this case all tissues were examined for cysts using a wet mount.

\section{RESULTS}

\section{Cyst survival and viability}

Cysts from all 3 gordiid species tested survived within Tanytarsus sp. imagos through metamorphosis (Fig. 1, part A; Table I). Cysts were found just outside the midgut or within the musculature. IDRs were noted sporadically (less than 5\%; data not shown), against all 3 species, and consisted of thin layers of hemocytes. In no case was the IDR noted to visibly affect cysts. 
TABLE II. Paratenesis of gordiids. Hosts exposed to cysts from 3 gordiid species, Gordius robustus, Paragordius varius, and Chordodes morgani. Data presented as number of hosts infected/number of hosts exposed.

\begin{tabular}{lccc}
\hline \multicolumn{1}{c}{ Host species } & G. robustus & P. varius & C. morgani \\
\hline Tenebrio molitor & $4 / 6$ & $6 / 6$ & $2 / 3$ \\
Zophobas sp. & $4 / 5$ & $1 / 2$ & $4 / 4$ \\
Gryllus firmus & $*$ & $*$ & $6 / 7$ \\
\hline
\end{tabular}

* Develops to adult stage in this host.

The cyst viability test of $P$. varius through insect metamorphosis (Fig. 1, part B), of the 15 crickets exposed to adult midges, 5 died before 30 DPE. Of the 10 remaining crickets, 5 were infected, and worms readily emerged when placed in water. None of the individuals in the control groups contained gordiids.

\section{Natural system}

Of the naturally infected mayflies, 2 of 8 Callibaetis sp. larvae contained cysts. Eleven of 24 adults contained cysts. Of the 4 cysts found in the larvae, a thick layer of hemocytes encased 1. Five of the 24 cysts found in the adults had elicited host IDR. The remaining 22 cysts, from the larvae and adults, looked normal, without signs of host IDR. However, this IDR did not cause the visible degradation or destruction of the cyst. Rather, it appeared only to isolate the cyst. Cysts eliciting an IDR were not restricted to specific host body regions. Infected and uninfected mayflies did not appear to differ morphologically or behaviorally. Cyst morphology was consistent with that of $G$. difficilis (Bolek and Coggins, 2002).

\section{Serial cyst passage}

Paratenesis was successful in all 4 trials (Fig. 1, parts $\mathrm{C}$ and D; Table II). Individuals of the 2 beetle species were infected with cysts of the 3 species of gordiids. Chordodes morgani cysts also established in the gut of G. firmus. Hosts maintained for as long as 42 days continued to retain cysts. In all secondary paratenic hosts, cysts were localized in the gut. It could not be determined whether the cysts were located in the lumen or within the epithelial cells. No further development was noted by any of the cysts, and their appearance was similar before and after passage. None of the individuals in the control groups contained cysts. Regrettably, it was not possible to count the number of cysts fed to each host. Therefore, the fraction of cysts surviving paratenesis is unknown.

\section{DISCUSSION}

Use of aquatic insects as paratenic hosts for American species of gordiids, using orthopteran definitive hosts, would require the following. First, the cysts must survive the metamorphosis of the paratenic hosts. Second, the host must not be able to mount an IDR efficient enough to substantially decrease cyst viability. Third, morphology and development of paratenic insect hosts must not be adversely affected by the presence of cysts. Fourth, the diet of potential definitive hosts must contain these paratenic hosts.

Cysts of all 3 species of gordiids tested in this study survived the metamorphosis of Tanytarsus sp. Experiments with $P$. var ius showed that these cysts remained viable and were infective to the definitive hosts. These findings support a life cycle for these gordiid species similar to that proposed for Chordodes japonensis, using mantid definitive hosts (Inoue, 1952). In that study, cysts produced in midges, mayflies, and mosquitoes survived, although the viability of cysts in each type of host differed because of the variation in IDRs. Clöeon-type IDR, normally associated with mayflies, consisted of hemocytes surrounding cysts in a spherical envelope, whereas Chironomustype IDR, normally observed in midges, was similar except that it also included a melanization reaction. Cysts in individuals of a mosquito species elicited both types of IDR (Inoue, 1960). Subsequent infection experiments suggested that the Chironomus-type IDR caused a sharp decrease in the viability of cysts (Inoue, 1962). Chironomus-type IDRs were not recorded from either host investigated in the current study but have been shown to occur in Culex tarsalis Coquillett, 1896, destroying cysts (Hanelt and Janovy, 2003). Similar results have been reported in the case of Culex pipiens Linnaeus, 1758, infected with Neochordodes occidentalis (Montgomery, 1898), using orthopteran definitive hosts (Poinar and Doelman, 1974). In this study, cysts were found to elicit IDRs more closely resembling Clöeon-type IDR in both Tanytarsus sp. and Callibaetis sp. These IDRs did not appear to harm cysts, although experimental determination of the effect of this IDR on the parasite has yet to be completed.

Insect hosts were not morphologically or developmentally affected by the presence of cysts. Although normal development was also reported in insect species infected with $C$. japonensis cysts (Inoue, 1960, 1962), it is not known whether these hosts are adversely affected in nature. White (1960), studying natural infection in 83 genera of aquatic insects in Wisconsin, found cysts in 6 genera of 4 orders. Parasitized individuals were found to vary morphologically from nonparasitized ones. For example, the wing pads of mayflies were found to be smaller. In addition, it was also reported that Simulium spp. (Diptera) and Brachycentrus sp. (Trichoptera) did not pupate, whereas a control group developed normally (White, 1969). In the current study, naturally infected Callibaetis sp. did not appear to differ from uninfected individuals and pupated and metamorphosed normally. Thus, the presence of cysts within the paratenic host species investigated in this study did not preclude the insects from potentially acting as natural paratenic hosts.

These data support the idea that cysts from G. robustus, $C$. morgani, and $P$. varius can encyst within and survive the transition of insects from an aquatic to a terrestrial environment. Thus, the final link in establishing these hosts as a natural part of the life cycle is the presence of these paratenic hosts in the diet of their definitive hosts. Definitive hosts for G. robustus and $C$. morgani include species of orthopterans and blattodeans, whereas $P$. varius has been reported only from orthopterans, including Tettigoniidea and Gryllidea. Although the carnivorous nature of many members of Blattodera is well known (Tepper, 1900), many species of Orthoptera have also been recorded to consume insects. The presence of insect parts in the gut or in the feces has been reported from virtually all orthopteran groups (Gangwere, 1961). Carnivorous behavior, including the consumption of dead animal materials as well as injured weak- 
ened or dying prey, is especially prevalent among tettigoniids and gryllids (Gangwere, 1961). Thus, it is clear that aquatic insects that undergo metamorphosis are a natural part of the gordiid life cycle for gordiid species using orthopteran definitive hosts.

Besides encysting in these normal paratenic hosts, gordiids may also encyst in a wide variety of spurious hosts (Hanelt and Janovy, 2003). It has been suggested that cysts in these spurious hosts are at a dead end (Müller, 1920). However, as it has been shown in this study, it is possible for cysts to transfer from one paratenic host to another under laboratory conditions. Finding cysts for up to 42 DPE after paratenesis suggests that the presence of cysts is not merely due to the presence of undigested food material (snails) containing cysts but actually involves the transfer of cysts from one host to the next. Although field studies are still necessary to confirm the possibility of gordiid cyst transfer between hosts in natural systems, a similar type of transmission has been reported in other groups of parasites. Paratenesis has been documented in species of trematodes (Shoop, 1988), cestodes (Halvorsen and Wissler, 1973), and nematodes (Daengsvang, 1968). This type of transmission raises the intriguing possibility that cysts initially formed in spurious hosts could eventually be transmitted to a suitable definitive host. This mechanism also suggests that cysts could survive beyond the life span of a single paratenic host and indicates that the gordiid life cycle could include a large number of serial paratenic hosts.

Hosts not required for the proper development of a parasite life cycle were first called hôtes d'attente (Joyeux and Baer, 1936) and later translated to paratenic host (Baer, 1951). These hosts were defined as having important ecological roles such as closing an ecological gap in the life cycle. Aquatic insect hosts carrying gordiid cysts obviously fit this definition because most gordiids do not appear to need this host for development but provide an essential bridge from freshwater environments to terrestrial hosts. The role of the paratenic host may, however, extend beyond this definition. In the gordiid life cycle, insect paratenic hosts may function in maintaining individuals at a particular site. Gordiids commonly inhabit rivers and streams. In these environments, each life cycle stage, but especially adults, can be affected by drift-induced downstream displacement. Calculations based on several macroinvertebrate taxa suggested that downstream displacement may be as great as 10 $\mathrm{km}$ during a single generation (Hemsworth and Brooker, 1979).

Insects mitigate drift through the colonization cycle (Mottram, 1932; Müller, 1954). This hypothesis states that the upstream directed flight behavior exhibited by many freshwater aquatic insects compensates for the gradual downstream movement of insect larvae (Müller, 1982). More recently, the colonization cycle has also been shown for active upstream movement under water by aquatic insect larvae (Söderström, 1987). Gordiids may ultimately benefit from using paratenic insect hosts by the host's colonization cycle behavior. Thus, the colonization cycle not only mitigates drift by insects but also may do so for gordiid parasites.

\section{ACKNOWLEDGMENTS}

The authors gratefully acknowledge Richard E. Clopton and Matthew G. Bolek for providing insightful discussions about gordiid and aquatic insect biology, Cedar Point Biological Station for providing facilities, and 2 anonymous reviewers whose comments greatly improved the manuscript. A grant from the Initiative for Ecological and Evolutionary Analysis, University of Nebraska-Lincoln (UN-L), and the Gugler Memorial Award from the Special Funds Committee, School of Biological Sciences, UN-L, supported this work.

\section{LITERATURE CITED}

BAER, J. G. 1951. Ecology of animal parasites. University of Illinois Press, Urbana, Illinois, 224 p.

BlunK, H. 1922a. Die Lebensgeschichte der im Gelbrand schmarotzenden Saitenwürmer I. Zoologischer Anzeiger 54: 110-132.

- 1922b. Die Lebensgeschichte der im Gelbrand schmarotzenden Saitenwürmer II. Zoologischer Anzeiger 54: 145-163.

Bolek, M. G., AND J. R. CogGins. 2002. Seasonal occurrence, morphology, and observation on the life history of Gordius difficilis (Nematomropha: Gordioidea) from southeastern Wisconsin, United States. Journal of Parasitology 88: 287-294.

DAENGSVANG, S. 1968. Further observations on the experimental transmission of Gnathostoma spinigerum. Annals of Tropical Medicine and Parasitology 62: 88-94.

GANGWERE, S. K. 1961. A monograph on food selection in Orthoptera. Transactions of the American Entomological Society 87: 67-230.

Halvorsen, O., AND K. Wissler. 1973. Studies on the helminth fauna of Norway XXVIII: An experimental study of the ability of $D y$ pyllobothrium latum (L.), D. dendriticum (Nitzsch), and D. ditremum (Creplin) (Cestodes Pseudophyllidea) to infect paratenic hosts. Norwegian Journal of Zoology 21: 201-210.

HANELT, B., AND J. JANOVY JR. 1999. The life cycle of a horsehair worm, Gordius robustus (Gordioidea: Nematomorpha). Journal of Parasitology 85: 139-141.

- 2 AND 2000. New host and distribution record of Gordius difficilis (Nematomorpha: Gordioidea) from a vivid metallic ground beetle Chlaenius prasinus (Coleoptera: Carabidae) from western Nebraska, USA. Comparative Parasitology 67: 107-108. , AND - 2003. Spanning the gap: Identification of natural paratenic hosts of horsehair worms (Nematomorpha: Gordioidea) by experimental determination of paratenic host specificity. Invertebrate Biology 122: 12-18.

, AND - 2004. Untying a Gordian knot: The domestication and laboratory maintenance of a Gordian worm, Paragordius varius (Nematomorpha: Gordiida). Journal of Natural History 38: 939-950

Hemsworth, R. J., AND M. P. BROOKER. 1979. The rate of downstream displacement of macro invertebrates in Upper Wye Wales UK. Holarctic Ecology 2: 130-136.

INOUE, I. 1952. On a new species of Chordodes (Gordiacea) from Japan. Annotationes Zoologicae Japonenses 25: 400-402.

- 1960. Studies on the life history of Chordodes japonensis, a species of Gordiacia II. On the manner of entry into the aquatic insect-larvae of Chordodes larvae. Annotationes Zoologicae Japonenses 33: 132-141.

- 1962. Studies on the life history of Chordodes japonensis, a species of Gordiacea III. The modes of infection. Annotationes Zoologicae Japonenses 35: 12-19.

Joyeux, C., AND J. G. BAER. 1936. Les hôtes d'attente dans le cycle évolutif des helminthes. Biologie médicale 24: 1-6.

Meissner, G. 1856. Beiträge zur Antonomie und Physiologie der Gordiaceen. Zeitschrift für wissenschaftliche Zoologie 7: 1-140.

MotrRam, J. C. 1932. The living drift of rivers. Transactions of the Newbury District Field Club 6: 195-198.

MüLlER, G. W. 1920. Beobachtung an Gordius. Zoologischer Anzeiger 51: $225-229$.

MüLLER, K. 1954. Investigations on the organic drift in north Swedish streams. Reports of the Institute of Freshwater Resources of Drottningholm 34: 133-148.

- 1982. The colonization cycle of fresh water insects. Oecologia 52: 202-207.

Poinar, G. O. JR., and J. J. Doelman. 1974. A reexamination of Neochordodes occidentalis (Montg.) comb. n. (Chordodidae: Gordioidea): Larval penetration and defense reaction in Culex pipens $\mathrm{L}$. Journal of Parasitology 60: 327-335. 
Schmidt-RhaESA, A. 1997. Nematomorpha. Gustav Fischer, Stuttgart, Germany, $128 \mathrm{p}$.

SHOOP, W. L. 1988. Trematode transmission patterns. Journal of Parasitology 74: 46-59.

SÖDERSTRÖM, O. 1987. Upstream movements of invertebrates in running waters-A review. Archiv für Hydrobiologie 111: 197-208.

TePper, J. G. O. 1900. Notes on cockroaches in South Australia. Bul- letin of the U.S. Department of Agriculture Division of Entomology 22: 95-96.

ThORNE, G. 1940. The hairworm, Gordius robustus Leidy, as a parasite of the Mormon cricket, Anabrus simplex Haldeman. Journal of the Washington Academy of Sciences 30: 219-231.

WhITE, D. A. 1969. The infection of immature aquatic insects by larval Paragordius (Nematomorpha). Great Basin Naturalist 29: 44. 